\title{
ANALYSIS OF THE CASTLE LIBRARY AS A SOURCE OF NEW INFORMATION ON THE DEVELOPMENT OF THE LANDSCAPE GARDEN IN VLAŠIM
}

\author{
Barbara Ševčíková ${ }^{1}$ \\ ${ }^{1}$ Department of Garden and Landscape Architecture, Faculty of Horticulture, Mendel University in Brno, Czech \\ Republic
}

To cite this article: ŠEVČÍKOVÁ BARBARA. 2018. Analysis of the Castle Library as a Source of New Information on the Development of the Landscape Garden in Vlašim. Acta Universitatis Agriculturae et Silviculturae Mendelianae Brunensis, 66(5): 1207-1215.

To link to this article: https://doi.org/10.11118/actaun201866051207

\begin{abstract}
The research presented is concerned with the analysis of the Vlašim castle library aiming to contribute to the knowledge on a significant Czech landscape garden from the second half of the 18th century. Another objective was to verify what information this source can provide for research into the field of architectural and historical development of garden art monuments. The catalogue of the castle library in Vlašim was studied based on four main criteria - date of publishing, author, the topic of the publication together with specific features of the printed edition. With these aspects, the books that could be related to the creation and development of the garden have been selected. This relationship was further investigated at the interpretation stage, when relations between selected books and the garden were searched for as well as its relation to the development of garden art in Europe. It was found that the library contains publications by the leading philosophers of the Enlightenment as well as books dedicated to horticulture and garden art. The dedications on the flyleaves of some books support the theory that the founder of the garden was Prince William I of Auersperg. Other findings indicated a possible connection with the anglo-chinois garden prototypes at Monceau and Ermenonville. The found inventory of plants drafted by Antonín Hoborský provided the opportunity to observe a new line of information leading to possible relations to the residence in Herrenhausen, Germany. Based on the findings, it is possible to conclude that surveys of castle libraries can offer a range of important information, and should become a standard part of the architectural and historical surveys of garden art monuments.
\end{abstract}

Keywords: castle library, Auersperg, landscape garden, Vlašim, anglo-chinois, 18th century

\section{INTRODUCTION}

Garden at the castle in Vlašim (Wlaschim in German) in Central Bohemia, Czech Republic, was most likely founded by the Auersperg family in 1775-1778. It is one of the first examples of the English landscape garden ideas penetrating into the Czech lands. At the time of its creation, it was a very respected and admired garden. Still, the existing knowledge on the garden is only partial, although it is well preserved and pictorial documentation of the time of creation is available.

The texts on the development of the Vlašim garden published so far draw the data from several sources, used repeatedly, and contradictory information often 
appears. The contradictions are likely an outcome of using non-original materials, later editions of historical publications, or the unavailability of archival documents. Basic facts about the garden creation, the initial inspiration for its establishment, gardeners working there, artists and others are still unclear, sometimes are even subjects of speculations. It is still not known who was the originator of the concept and ideological content of the garden. According to some scholars (e.g. Vlasák 1874), this was the owner of the estate, Duke Karl Joseph of Auersperg (1720-1800), other authors (Svoboda and Moudrý 2006) mentioned his wife, Duchess Marie Josepha of Trautson (1724-1792). There is also an opinion indicating a joint authorship of both of them (Slavík 1889); additionally, their eldest son, Prince William I of Auersperg (1749-1822), the main heir to the family estates is considered to be the initiator and the main creator of the garden (Pincová 2015).

Hardly any archival documents that would support the hypotheses are available. This is most likely due to the fragmentation of the Auersperg family archives and bad accessibility of the archives. Most of the materials potentially interesting for the development of the Vlašim garden are kept in various, often private, archives in Austria. In such cases, an analysis of the period content of the castle library may be a good alternative source of knowledge of the garden development, as shown in studies by e.g. Stejskalová (1997) and Antonín (1997, 2006). The process of architectural and historical survey of garden art monuments apparently does not include analysis of castle library catalogues as standard, as indicated in the certified methodology by Krejčiřík and Pejchal (2015). One of the objectives of this study was to demonstrate that the results of analyses of castle library catalogues can contribute to the knowledge on garden development.

Researchers (in particular Pincová 2010 and 2015) studying the Vlašim garden have not yet explored the Auersperg castle library. The author of this article found out that the catalogue of this library is kept in the Library of the National Museum in Prague - Department of Castle Libraries, and is available for study. The main objective of this article is to present the results of the analysis of the above-mentioned catalogue, which has also been examined related to the development of garden art in Europe. The analysis focuses on the identification of horticultural and other literature that could be related to the composition, the ideological content and the development of the Vlašim landscape garden in the second half of the 18th century.

\section{MATERIALS AND METHODS}

All the known and available materials of different nature (apart from archive sources), devoted to the form and development of the Vlašim garden, have been studied in preparation of this article. Their study was important for the knowledge of the overall state of the issue as well as for the context of the planned analysis of the Vlašim castle library. The study does not include an archive survey as that would be very troublesome, time-consuming and would require a multidisciplinary approach in the case of the Auersperg family and the Vlašim estate. However, basic archival maps have been included. The indication sketch of 1841 (National Archive, Fund 56, Signature: KRM438018410) has proven to be the best source of information. It is the most accurate map known so far that shows the appearance of the garden in the first half of the 19th century, i.e. roughly 60-70 years after its creation.

Historical descriptions from the 19th century (Slavík 1889; Vlasák 1874) were studied in their original (first) edition. In addition to these two known authentic descriptions, the author has drawn on another, in Czech literature yet unpublished text, provided by the gardener at Herrenhausen, H. L. Wendland (1867/1868).

So far, several partial texts within overviews (e.g. Dokoupil et al. 1957, Pacáková et al. 1999, Svoboda and Moudrý 2006) and a monograph summarizing the basic facts (Pincová 2010) have been published on the Vlašim garden. The author of the monograph also probably published the most recent text on the Vlašim garden, introducing a new hypothesis about a potential founder of the garden (Pincová 2015). There is an older unpublished construction and historical survey dedicated to the structures in the castle garden (Kašička and Novosadová 1983).

An important source of knowledge of the form of the Vlašim garden is also the preserved collections of graphics. The research uses a complete file of "exactly by nature drawn" 25 coloured lithographs published by F. K. Wolf (1803) and Hoffman's 24 black-and-white engravings without dates (published by Franz Hoffmann in Prague, without naming the painter and the engraver).

Published sources focusing on surveys of castle libraries, with information on the field of garden art (Stejskalová 1997, Antonín 1997) were used as auxiliary literature. Additionally, an unpublished study by Mašek (undated) providing a brief summary of the content of the Vlašim castle library was employed. The information necessary to find the context was provided by other literature, including the original historical literature (Hunt 2002, Kroupa 1987, Preinfalk 2006, Carmontelle 1779, Girardin 1777, Hirschfeld 1779, Adámková, 2002).

The above mentioned sources provided the initial information for the following part of the study, which was the exploration of the original Auersperg castle library catalogue, kept in the Library of the National Museum - Department of Castle Libraries.

Naturally, a survey in situ was an indispensable part of the research. 


\section{The research method}

Survey of the Vlašim castle library was conducted at four main stages, which chronologically followed each other:

\section{Stage I - Analysis:}

- Search for and study of all available publications and other sources of information, maps and collections of graphics. Field survey focused on the photographic documentation of the existing state of the garden in Vlašim and the detection of the remains of the original composition (Fig. 1).

\section{Stage II - Synthesis}

- Summary of the bibliographic search for the sources gained at stage I, with all relevant findings and data, and its synthesis with the results of the field survey and the indication sketch (1841).

\section{Stage III}

- Survey of the original Auersperg castle library catalogue (from years 1983-1985)

- The catalogue contains 3504 volumes in total; publications that might be related with the creation, development and design of the Vlašim landscape gardens were searched for. The first key to identify relevant publications was the year of issue - books from 1770 (1750)-1800 (1820), i.e. The initiation period and the peak period of the garden formation, were identified. Another identifier was the topic - horticulture, agriculture or landscape (forestry). The third selection criterion was the authorship - interesting books were written by authors who had links to garden art or authors whose works could be related to the Vlašim garden. Since it is not discoverable when the books were taken to the library, it is assumed that they were obtained around the date of the release of the book. Greater certainty of ownership and acquisition time provides specifics of a book. Therefore, as the final step, specifics of the publications were searched-hand-written notes, dedications, ex-libris etc. The documents from stage II served for a preliminary estimation of the possible relations which could be further examined at stage IV.

\section{Stage IV - Interpretation}

- Processing of the results of the library catalogue survey: interpretation of the selected books - indications of possible relations, new information, context with the development in Europe and other possible lines of research.

\section{RESULTS}

The Vlašim castle library currently contains 3504 volumes, of which 1184 prints are from the period before the end of the 18th century. Roughly two thirds of the library are publications in German, the others are in French, with a few exceptions (more recent literature) in Czech (Mašek, undated). No publication is in English, books related to England or Great Britain are exceptional, only complementing the library collection. About one third of the library is from the life of Duchess Marie Josepha of Trautson (before 1792), Duke Karl Joseph of Auersperg (before 1800) and their oldest children - in particular, Prince William (from about 1755).

The survey took account of the date of publication, the topic, authorship and any specifics of the edition stored in the library. It was found that there are several writings by J. J. Rousseau, including his collected works, some books are translated to German. The oldest publication "Les Pensées de J. J. Rousseau" comes from 1773, further "J. J. Roussean 's Bekenntnisse. Geschichte seines männlichen Alters" (translated from French, Confessions - Battles of Manly Years), 1780, "Geständnisse von J. J. Rousseau nebst den Selbstbetrachtungen des einsamen Naturfreundes" (translated from French, Reveries of a Solitary Walker), 1782, "Oeuvres completes de J. J. Rousseau" (J. J. Rousseau's Complete Work), 1792, "La nouvelle Héloise ou Lettres..." (1798). The extensive, almost complete collection of J. J. Rousseau's work in

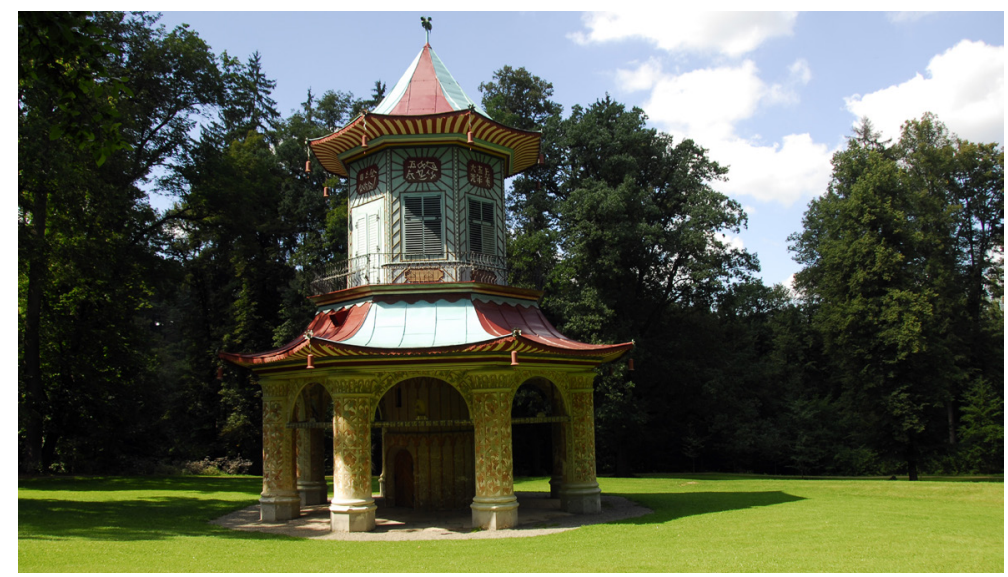

1: Chinese temple in the Vlašim garden, August 2016 Photo by author 
the Vlašim castle library supports the idea of a possible relation to the garden at Ermenonville (1762-1778), which was expressed by Adámková (2002). The circular monopteros of Cupid's Temple on an artificial island in the middle of the lake (Fig. 2) surrounded by slender trees (probably Populus nigra 'Italica') could symbolically point to the garden at Ermenonville established by Marquis René Louis de Girardin (1735-1808); specifically, to the place where Jean Jacques Rousseau (1712-1778) was originally buried in 1778 - I 'Isle des Peupliers (Fig. 3). The tomb on the island at Ermenonville did not have a shape of a circular temple, but the theme of the island, surrounded by vertical lines of poplars, associates the similar situation in Vlašim. Additionally, the theme of monuments, marked in some cases by stone urns, is also common in the Vlašim garden, as apparent from the analysis of F. K. Wolf's set of graphics (1803).

As regards literature on horticulture, there are publications published in Hanover, Göttingen, Mannheim and Leipzig, the first from 1780, the others from 1781, 1785, 1792, 1794, 1795-96.
They are mainly books on practical gardening or descriptions of North American tree species (in chronological order):

- Karl Gottlob Feuereisen-"Praktische Abhandlungen über einige wichtige Gegenstände in der feinen Gärtnerey", Hannover, in der Helwingischen Hof - Buchhandlung, 1780, XXXII, 320 p.

- Friedrich Adam Julius Wangenheim-"Beschreibung einiger Nordamericanischen Holz - und Buscharten, mit Anwendung auf teutsche Forsten". Göttingen, bey Johann Christian Dieterich, 1781, 151 p.

- FriedrichKasimirMedicus-"Uebernordamerikamische Bäume und Sträucher, als Gegenstände der deutschen Forstwirthschaft und derschönen Gartenkunst". Von Friedrich Casimir Medicus. Mannheim, bei Schwan und Götz, 1792, 96 p.

- Christian Johann Friedrich von Dieskau - "Vortheile in der Gärtnerey in vermischten Abhandlungen von Christ. Johann Friedrich von Diesskau". 2te revidirte Auflage von C. P. Pezold. Band 2. Coburg, bey Rudolph August Wilhelm Abl., 1794, 412 p.

- Johann Heinrich Albonico - "Nützliche Bemerkungen für Garten - und Blumenfreunde. gesammlet von Johann

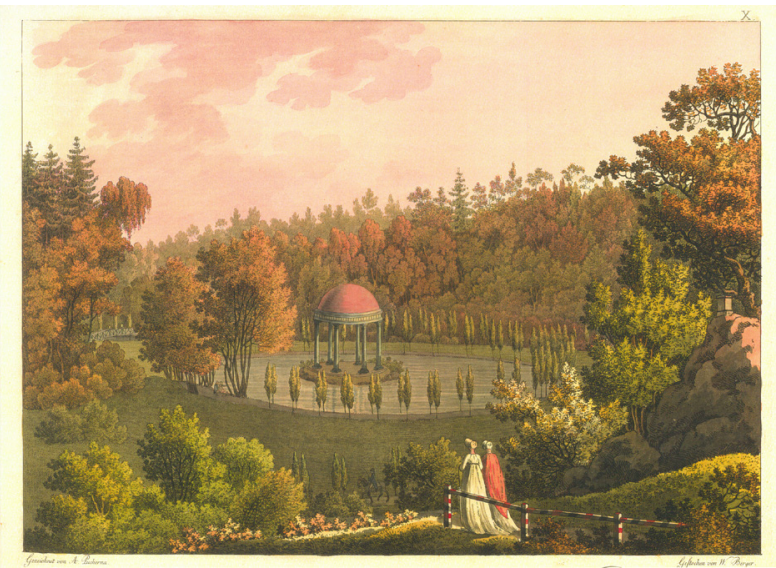

2: Cupid's Temple on the island surrounded by poplars Pucherna and Berger In: Wolf, 1803

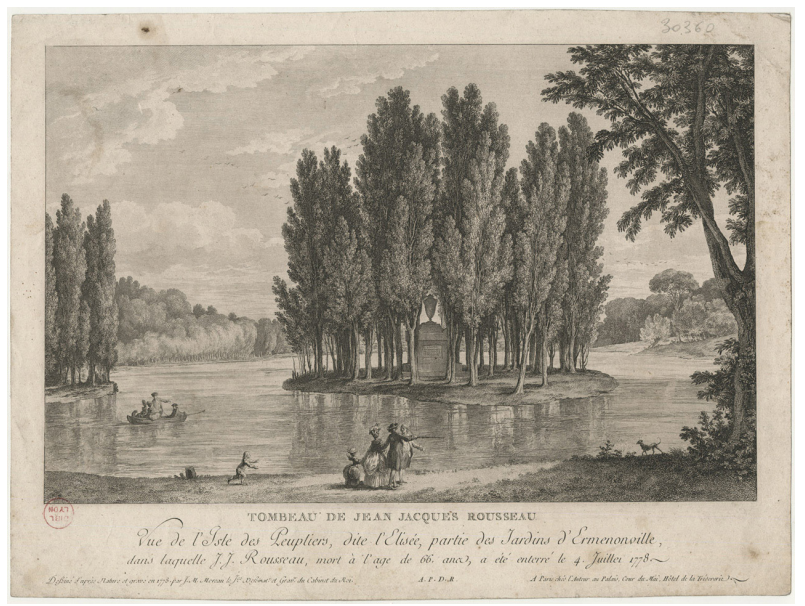

3: J. J. Rousseau's tomb at Ermenonville - I'Isle des Peupliers, undated http://jeanjacquesetmoi.blogspot.com/2012/07/lile-des-peupliers_4587.html 
Heinrich Albonico". Heft 1., 3. Leipzig, bey Gerhard Fleischer, 1795-1796, 2 volumes.

The earliest publication found in the catalogue with agricultural or horticultural topic is a treatise by Henri Louis Duhamel du Monceau, who was an important scientist focusing among others on botany, horticulture, agriculture and forestry. His book (German translation from French) "Abhandlung von dem Ackerbaue, nach den Grundsätzen des Herrn Tull, eines Engelländers, französisch herausgegeben von Herrn du Hamel du Monceau" (Dressden, Verlegts, Georg Conrad Walther, 1752, 342 p.) is based on the principles of the English innovator of agricultural practices, Jethro Tull (1674-1741).

None of the above listed books devoted to gardening brings information related to the composition of the Vlašim garden. It is only apparent that the interest in horticultural literature started to grow considerably in the 1780 s, i.e. in the period when the garden was established. It can also be stated that this literature was exclusively German or translated into German.

An interesting finding was an anonymous publication, titled "Beschreibungen von Gärten zur Ehre deutscher Kunst und deutschen Geschmack", Altona, bey J. H. G. Hellmann, 1785, XII. According to a review on this book in Allgemeine Literatur-Zeitung of January 1785, the author was Christian Cay Lorenz Hirschfeld (1742-1792), known primarily as the author of 5-volume Geschichte der Gartenkunst (1779-1785). This work, though frequent in Czech castle libraries (e.g. according to Antonín 1997 in castles Červený Hrádek u Chomutova, Konopiště, Nové Hrady, Budíškovice, Klášterec nad Ohř́i, and others), was not found in the catalogue. However, the presence of the more concise "description of the gardens by the German taste" could have some influence on the Vlašim composition. The influences of the German cultural environment on the appearance of the Vlašim garden should be investigated in a comparative study in the future.

As regards the specifics of the publications in the catalogue, some prints with dedications on a flyleaf were discovered: "A Guillaume
Auersperg" - "to William Auersperg". It is found in F. M. A. de Voltaire's "Grenier a Sel ou recueil nouveau, contenant des bons Mots, des Pensées ingénieuses, des Saillies vives, des Contes divertissans, des Dialogues, des Réflexions et des maximes Morales et Critiques" from 1730. The same dedication (A Guillaume Auersperg) is found in flyleaves of all eight volumes of "Amusemens de société ou Proverbs dramatiques" (Amsterdam, 1770) by Louis Carrogis Carmontelle (1717-1806), the creator of one of the first landscape gardens in France - at Monceau (1773-1778). It is likely that a significant writing of the English representative of the Enlightenment, John Locke, in the French translation "Le christianisme raisonable, tel qu il nous est représenté dans l ecriture Sainte" from 1740 comes from the same source as the previous two books. Additionally, the first set of J. J. Rousseau's ideas in French from 1773 falls in this group too. Later, an increasing amount of books on horticulture can be observed as well as more J. J. Rousseau's works, part of them in the German translation. Their topic is not horticulture, but they are interesting as regards the dedications.

With respect to the above listed findings, the hypothesis can be formulated that the young Prince William I of Auersperg (in French Guillaume) travelled to Paris during his Grand Tour, where he either directly met L. C. Carmontelle or other personalities of the Enlightenment, who donated him some (or all) of the above titles. Studying new philosophical treatises by Voltaire, Rousseau or Locke meant enlightened, creative environment. There are no evidences whether Prince William actually got into personal contact with L. C. Carmontelle or even visited his emerging garden at Monceau or not. But it is clear from comparison of both the gardens (Vlašim and Monceau) that they had at least one strong similarity. The garden at Monceau was the French type of the landscape garden, called anglo-chinois or jardin anglaise. One of its distinctive features was a large number of small garden structures, called fabriques (Fig. 4). There were around 30 such structures in Vlašim; in Monceau, on a much smaller area of

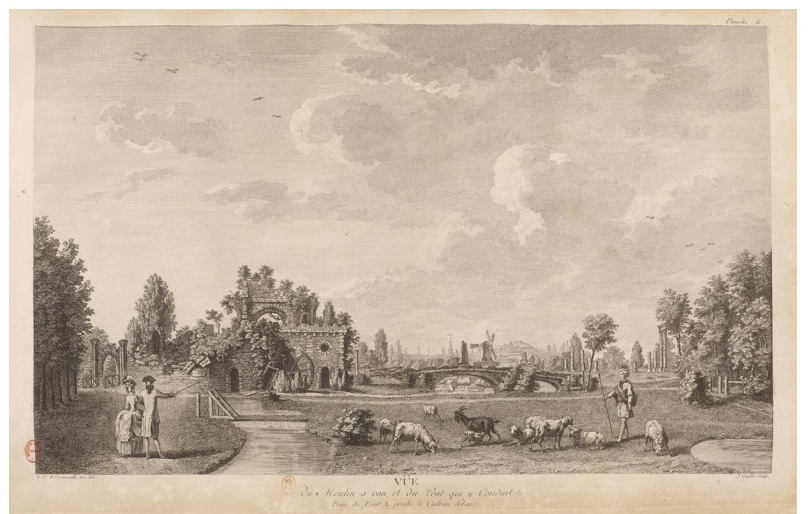

4: Garden at Monceau - Water mill in the foreground, other fabriques in the background Carmontelle 1779, available at: https:/gallica.bnf.fr/ark:/12148/bpt6k1066592n/f21.image 
18 hectares, there were about 25 of them. Further comparisons of the two gardens could yield more detailed information on their possible relationship.

After 1800, the Auersperg library was further supplemented with various horticultural literature and magazines, but this period is no longer determining for the creation and development of the garden. An important discovery from this period was the catalogue from 1814 "Verzeichniss der sämmtlichen Treib - und Glashaus - Pflanzen, exotischen Gehölze, wie auch im Freyen ausddaurenden Staudengewächse und Sämereyen, welche zu haben sind bey dem fürstlichen Hofgärtner Anton Hoborsky zu Wlaschim, im Königreiche Böhmen." Prag, gedruckt bey Franz Sommer, unpaged. I.e. an inventory of all greenhouse, exotic and wild shrubs and seeds that are available at the Ducal Supreme Gardener Anton Hoborsky in Vlašim in the Kingdom of Bohemia. Using more detailed information by Paulus (2016), it can be concluded that the gardener Antonín Hoborský (Anton Hoborsky) really worked in Vlašim at the beginning of the 19th century. Additional information is provided by Peters (2013), who confirms Antonín Hoborskýs position in Vlašim, and allows expanding the research into the Vlašim garden in a new direction - the residence in Herrenhausen, Hanover.

\section{DISCUSSION}

The survey of the castle library has brought interesting facts, some of which support previously expressed assumptions. In contrast, other results allow creating new theories. One of them is the symbolism of the Cupid's Temple in Vlašim. Pincová (who published so far only one partial monograph on the Vlašim garden in 2010) compares it to the Cupid's Temple in the Petit Trianon at Versailles, which she considers a probable inspiration for the Vlašim Temple. Cupid's Temple in the Petit Trianon at Versailles was opened in 1778, the island with the poplars and J. J. Rousseau's tomb was completed in the same year. It is true that the two temples are similar as regards visual and theme-related aspects (the Versailles temple is more ornate), as well as the location on an artificial island and on the plane. However, the mood created by the slender poplar trees strongly reminds of Ermenonville, Isle de Peupliers. The following questions remain: What is the origin of the specific use of pyramidal trees in Vlašim? Could this be homage to the admired philosopher?

The notes on flyleaves of books can be interpreted variously, but theories of the effect of the French environment on the creation of the Vlašim garden have already been expressed (e.g. Adámková 2002; Pincová 2010); finding books with the mentioned dedication only supports them. It is highly probable that the young Prince William I of Auersperg travelled around Europe at his Grand Tour in 1770-73, when he was 21-24 years old, and Paris used to be a must of such tours. He could meet and be inspired by L.
C. Carmontelle and a circle of his friends - however, this hypothesis can only be confirmed if archival documents are found. The most recent paper on the garden titled "History of the Vlašim Masonic park" (Pincová, 2015) provides reflections on the possible founder of the garden and develops theories previously expressed by other authors about the Masonic symbolism. Taking account of the findings within this survey, the theory of Pincová (2015) about Prince William as a possible main author of the garden can be supported. He certainly was the person who brought the idea to build a new landscape garden at the residence of his parents in Vlašim in the existing attractive environment of the original game park. Prince William's interest in garden art can be demonstrated, for example, by him ordering an extensive collection of graphics from the Prague publisher, F. K. Wolf (1803), depicting all of the major motives of the Vlašim landscape garden. However, without archival documents, this is still a hypothesis, though supported by a number of indirect evidence.

Contacts with the French environment may further be confirmed by the fact pointed out by Antonín (undated). The Cupid's Temple in Vlašim was published in the French version of Grohmann's Ideenmagazine called Recueil d'Idées Nouvelles pour la Décoration des Jardins et le Parcs..., Cahier XXXVII, sous la direction de J. G. Grohmann, á Paris et á Strasbourg, from 1802. The stencil (or any other similar) does not appear in the catalogue of the Vlašim castle library, but the enlistment of the engraving proves the relevance and importance of the garden at that time.

French influences on the appearance of the Vlašim garden are evident from the survey. What about the effect of the German environment? Most of the literature examined in the catalogue is in German, as well as horticultural literature. The finding of C. C. L. Hirschfeld's writing means familiarity with his theories. According to Pincová (2010), citing a note from an unpublished holiday journal of student F. X. Smrček from 1838, the Grove of Bards (Fig. 5) is supposed to contain statues of German poets - Herder, Lessing, Klopstock, Gellert, Schiller - each of them had his own place there. It is not clear where the statues were added. Vlasák (1874) or Slavík (1889) do not mention them, they are not present at any reproduction. A. Pucherna's graphics (In Wolf 1803) show the presence of various stone urns and vases (Fig. 6) or melancholy of some recesses and other details probably come from the German environment.

The author of this paper did not investigate the books themselves, only the catalogue. This research has to be further refined by going through the selected books in the castle library and focus on finding handwritten notes, inserted sheets and other authentic evidence of the publication usage.

Results and the discussion confirm that research into castle libraries can significantly assist in 


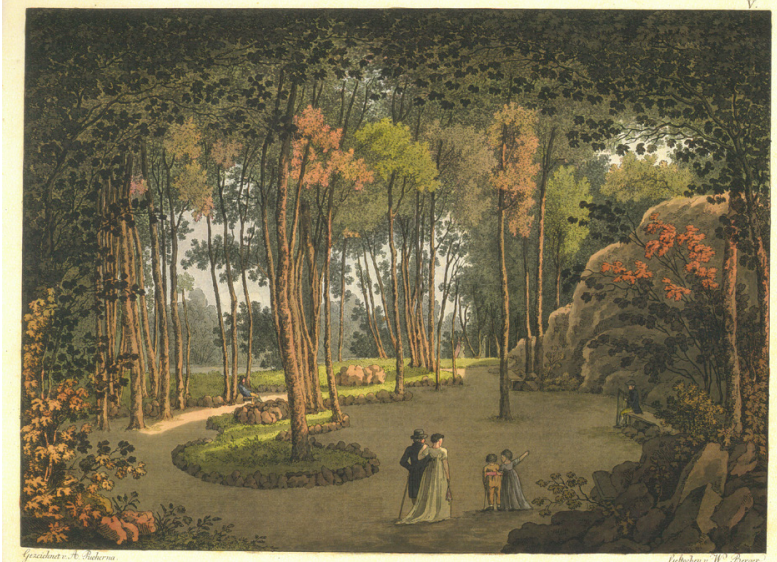

5: Grove of Bards in Vlašim Pucherna and Berger In: Wolf, 1803

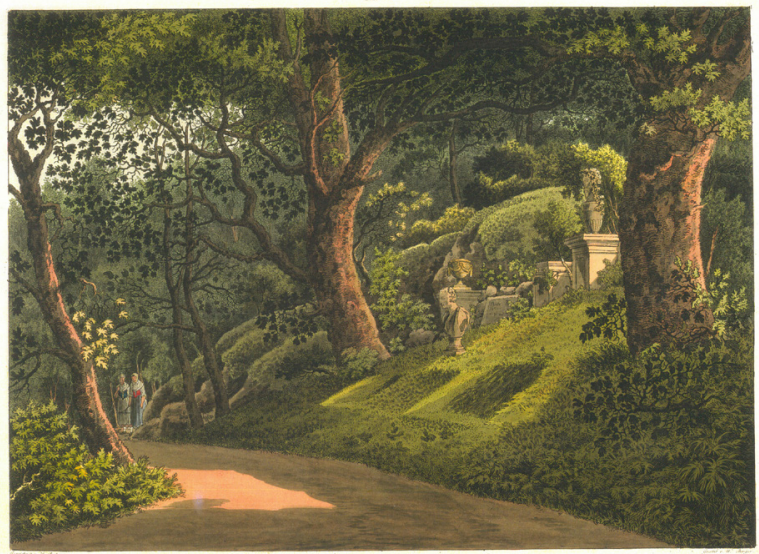

6: Vlašim - a recess dedicated to the antique god Bacchus, supplemented by stone vases and pedestals, in the foreground a bust of undetermined meaning Pucherna and Berger In: Wolf 1803

the architectural and historical surveys of garden design monuments and should be a standard part of methodological procedures. It can particularly help in the cases when the other essential documents are difficult to access or missing.
The analysis procedure chosen in this case study has defined universally applicable criteria to examine. However, the criteria should be updated or modified depending on the nature of the object investigated and the degree of its knowledge.

\section{CONCLUSION}

It has been proven that the development of the Vlašim landscape garden was influenced by the French and German cultural environments; however, the intensity of the effect cannot be accurately assessed. The analysis of the castle library catalogue showed that there were significant philosophical writings of the leaders of the new currents of thought, the Enlightenment - J. J. Rousseau, F. M. A. de Voltaire, J. Locke - who were reflected in the European garden art, and who could (also) inspire the establishment of the new type of garden in Vlašim.

The library contains horticultural literature, which began to appear there from the 1780s, i.e. during the time when the landscape garden was probably being prepared. The most famous author related to horticulture was the German Professor C. C. L. Hirschfeld: there is his publication devoted to the description of the garden type by German taste. The library was then supplemented with other horticultural literature and magazines. The most interesting publication from the period after 1800 is an inventory of all plants of the Vlašim garden by gardener Antonín Hoborský from 1814. Thanks to this publication, the links of the owners of the Vlašim estate to German Herrenhausen could be identified. Some of the publications in the catalogue are dedicated to William Auersperg. This finding supports the earlier expressed theory about a significant authorship of the young prince in the formation 
of the new Vlašim garden. In particular, the dedication inscribed within the 8 volumes of L. C. Carmontelle's work opens up the opportunity to further investigate the links of the Vlašim garden to the prototype of the French anglo-chinois at Monceau.

The results and the discussion confirm the importance of the analysis of a castle library when conducting architectural and historical survey of objects of garden art.

In conclusion, it can be stated that the survey of the Auersperg castle library provided new knowledge that allowed publishing of facts unknown so far, and opened up several new directions for possible future research. It can help find details about the conditions of the origin, the composition and the development of the Vlašim garden, which is a unique document of a specific historical epoch. Only sufficient and correct information can lead to a suitably selected restoration of the castle garden, which has become a city park in the meantime. Currently, its gradual recovery and adaptation is in progress. It is highly topical to have most complete picture of its historic appearance for these activities so that improper interference with the composition, content and other essential features of the unique garden is prevented. Only professionally and sensitively renovated historical garden can respond to the current needs and as such should be passed to the following generations.

\section{Acknowledgements}

The paper has been prepared with support of project No DG16P02H053 - Czech Garden Art and Landscape Architecture in the Context of European Development of the Program to support applied research and development of national and cultural identity for the years 2016 to 2022 (NAKI II), financed by the Ministry of Culture of the Czech Republic.

I would like to thank PhDr. Petr Mašek, Head of the Department of Castle Libraries, Library of the National Museum in Prague, for friendly assistance and cooperation.

\section{REFERENCES}

ADÁMKOVÁ, B. 2002. The English landscape school and its reflection in our territory [in Czech: Anglická krajinárská škola a její odraz na našem území]. Dissertation thesis. Lednice: Mendelova zemědělská a lesnická univerzita v Brně, Fakulta zahradnická, Ústav zahradní a krajinářské architektury.

ANTONÍN, L. 1999. Contributions to the iconography of castle gardens and spa parks from castle libraries [in Czech: Př́spěvky k ikonografii zámeckých zahrad a lázeňských parků ze zámeckých knihoven]. Zprávy památkovépécé, 59(7): 221-226.

ANTONÍN, L. 1997. Small garden architecture in the master books of castle libraries [in Czech: Drobná zahradní architektura v předlohových knihách zámeckých knihoven]. In: MYŽKOVÁ, M. (Ed.). Kamenná kniha. Sborník k romantickému historismu a novogotice. Sychrov: Zámek Sychrov. pp. 236-241.

ANTONÍN, L. 2005. From the library into the garden and back [in Czech: Z knihovny do zahrady a zpét]. 4. 05. 2005-30. 09. 2005, National Museum, Ždár nad Sázavou.

CARMONTELE, L. C. 1779. Jardin de Monceau, près de Paris, appartenant à S. A. S. Mgr. le duc de Chartres / (Texte et planches par Carmontelle). Paris: Delafosse. Available at: https://gallica.bnf.fr/ark:/12148/bpt6k1066592n. image [Accessed: 14.06.2018].

DOKOUPIL, Z., NAUMANN, P., RIEDL, D. et al. 1957. Historical Gardens in Bohemia and Moravia [in Czech: Historickézahrady v Čechách a na Moravè]. Praha: NČVU.

GÉRARDIN, R.-L. DE. 1777. De la composition de paysage ou des moyens démbellirs la Nature autour des Habitations, en joignant l'agréable al' utile. Paris (Genève): P. M. Delaguette. Available at: https://gallica.bnf.fr/ark:/12148/ bpt6k85712r.image [Accessed: 26. 06. 2018]

HIRSCHFELD, C. C. L. 1779 (2016). Theorie der Gartenkunst. Bd. 1. Digitale Edition von Jochen A. Bär. Vechta. Quellen zur Literatur- und Kunstreflexion des 18. und 19. Jahrhunderts, Reihe A, Nr. 1601/1. Leipzig. Available at: http://www.zbk-online.de/texte/A1601-001.htm [Accessed: 19.04. 2018]

HELLMANN, J. H. G. 1785. Beschreibungen von Gärten zur Ehre deutscher Kunst und deutschen Geschmacks, rezension. Allgemeine Literatur-Zeitung, 1(12): 55. Available at: http://zs.thulb.uni-jena.de/ receive/jportal_jparticle_00024811 [Accessed:2018, March 25].

HOFFMANN, F. undated. Graphic collection. Praha: F. Hoffmann.

HUNT, J. D. 2002. The Picturesque Garden in Europe. London: Thames and Hudson.

KREJČIŘÍK, P. and PEJCHAL, M. 2015. Architectural - historical survey of a landscape architecture monument [in Czech: Architektonicko - historický prïzkum památky krajinárské architektury]. Certified methodology. Lednice: ZF MENDELU. Available at: http://www.nczk.cz/useruploads/files/METODIKA\%20AHP_ KrejcirikPavlackaPejchal_s_c.pdf [Accessed: 2018, May 15].

KROUPA, J. 1987. The Alchemy of Happiness. The late Enlightenment and the Moravian society [in Czech: Alchymie štěstí. Pozdní osvícenství a moravská společnost]. Brno: Muzejní a vlastivědná společnost.

MAŠEK, J. undated. Vlašim castle library [in Czech: Vlašimská zámecká knihovna], not published.

NOVOSADOVÁ, O. and KAŠIČKA, A. 1983. Vlašim-structures in the castlepark. Architectural andhistoricalsurvey-text [in Czech: Vlašim - objekty v zámeckém parku. Stavebněhistorický pri̊zkum - textová cáast]. Praha: SÚRPMO. 
PACÁKOVÁ-HOŠŤÁLKOVÁ, B., PETRŮ, J. and RIEDL, D. 1999. Parks and gardens in Bohemia, Moravia and Silesia [in Czech: Zahrady a parky v Čechách na Moravéa ve Slezsku]. Praha: Libri.

PAULUS, F. 2016. History of the botanical garden in Smichov in the light of archive sources. New knowledge on the history of botany in the Czech land at the turn of the 19th century [in Czech: Dějiny botanické zahrady na Smíchově ve světle archivních pramenů. Nové poznatky k dějinám botaniky v českých zemích na přelomu 18. a 19. století]. Dissertation thesis. Praha: Univerzita Karlova v Praze, Filozofická fakulta, Katedra pomocných věd historických a archivního studia.

PETERS, K.. 2013. Die Hofgärtner in Herrnhausen. Werk und Wirken unter Besonderer Berücksichtung der „Gürtnerdynastie"Wendland. München: AVM.

PINCOVÁ, V. 2010. History of the romantic park in Vlašim: castle and park Vlašim [in Czech: Historie romantického parku ve Vlašimi: zámek a park Vlašim]. $2^{\text {nd }}$ Edition. Vlašim: Český svaz ochránců přírody Vlašim, 02/09 základní organizace.

PINCOVÁ, V. 2015. History of the Vlašim Masonic park [in Czech: Historie vlašimského zednářského parku]. Acta musei nationalis Pragae C - Literární historie, 60(3-4): 55-62.

PREINFALK, M. 2006. Auersperg. Geschichte einer europäischen Familie. Issue preparation Ernst Bruckmüller; translation Irena Bruckmüller-Vilfan. Graz: Stocker.

SLAVÍK, F. A. 1889. History of Vlašim and its estates [in Czech: Dějiny města Vlašimě a jeho statku]. Tábor: Čtenářský spolek ve Vlašimi. Available at: http://kramerius.nkp.cz/kramerius/MShowMonograph. do?id=24250 [Accessed: 2018, March 21].

STEJSKALOVÁ, E. 1997 Books about English gardens in the Castle Kačina [in Czech: Knihy o anglických zahradách na zámku Kačině]. In: MYŽKOVÂ, M. (Ed.). Kamenná kniha. Sborník k romantickému historismu a novogotice. Sychrov: Zámek Sychrov, pp. 222-235

VLASĂK, A. N. 1874. Vlašim District. A historical and archaeological outline [in Czech: Okres Vlašimský. Nástin historicko-archeologický]. Praha: Fr.A Urbánek, kněhkupec. Available at: http://kramerius.nkp.cz/kramerius/ handle/ABA001/10634219 [Accessed: 2018, March 26].

SVOBODA, J. and MOUDRÝ, J. 2006. Vlašim in the footsteps of ancestors. [in Czech: Vlašim po stopách předkị]. Praha: Vyšehrad

WENDLAND, H.L. 1867/1868. Lebensgeschichtedes Heinrich Ludolph Wendland, Königl.Hannov. Hofgarten-Inspektors in Herrenhausen (1792 - 1869). Manuscript in: Königliche Gartenbibliothek Herrenhausen - Nachlass der Hofgärtnerfamilie Wendland. Available at: http://kulturerbe.niedersachsen.de/viewer/piresolver?id=isil_ DE-35_wendlebe_00055889 [Accessed: 2018, Juni 13].

WOLF, F. K. 1803. Der fürstlich Auerspergische Park zu Wlaschim in Böhmen auf XXIV grossen, genau nach der Natur gezeichnet und in der neusten Manier ausgemahlten Blättern dargestellt. Praha: F. K. Wolf.

\section{Historical maps:}

The indication sketch of Vlašim, 1841. National Archive, Fund 56, Signature: KRM438018410, section A05A, A05B, A05B, A06B, the electronic copy kindly provided for NAKI research. 